University of Nebraska - Lincoln

DigitalCommons@University of Nebraska - Lincoln

West Central Research and Extension Center, North Platte

Agricultural Research Division of IANR

$8-2020$

\title{
Differences in soil water changes and canopy temperature under varying water $\times$ nitrogen sufficiency for maize
}

\author{
Tsz Him Lo \\ University of Nebraska-Lincoln, tszhimlo@huskers.unl.edu \\ Daran Rudnick \\ University of Nebraska-Lincoln, daran.rudnick@unl.edu \\ Kendall C. DeJonge \\ Water Management Research Unit, USDA-ARS, kendall.dejonge@ars.usda.gov \\ Geng Bai \\ University of Nebraska-Lincoln, gbai2@unl.edu \\ Hope Njuki Nakabuye \\ University of Nebraska-Lincoln, nakabuye.hope.njuki@huskers.unl.edu
}

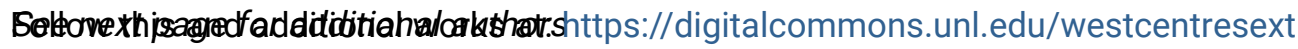 \\ Part of the Agriculture Commons, Bioresource and Agricultural Engineering Commons, Ecology and Evolutionary Biology Commons, Hydraulic Engineering Commons, Plant Sciences Commons, and the Water Resource Management Commons}

Lo, Tsz Him; Rudnick, Daran; DeJonge, Kendall C.; Bai, Geng; Nakabuye, Hope Njuki; Katimbo, Abia; Ge, Yufeng; Franz, Trenton E.; Qiao, Xin; and Heeren, Derek M., "Differences in soil water changes and canopy temperature under varying water $\times$ nitrogen sufficiency for maize" (2020). West Central Research and Extension Center, North Platte. 122.

https://digitalcommons.unl.edu/westcentresext/122

This Article is brought to you for free and open access by the Agricultural Research Division of IANR at DigitalCommons@University of Nebraska - Lincoln. It has been accepted for inclusion in West Central Research and Extension Center, North Platte by an authorized administrator of DigitalCommons@University of Nebraska Lincoln. 


\section{Authors}

Tsz Him Lo, Daran Rudnick, Kendall C. DeJonge, Geng Bai, Hope Njuki Nakabuye, Abia Katimbo, Yufeng Ge, Trenton E. Franz, Xin Qiao, and Derek M. Heeren 


\title{
Differences in soil water changes and canopy temperature under varying water $\times$ nitrogen sufficiency for maize
}

\author{
Tsz Him Lo ${ }^{1,6} \cdot$ Daran R. Rudnick ${ }^{1,3} \cdot$ Kendall C. DeJonge $^{2} \cdot$ Geng Bai $^{3} \cdot$ Hope Njuki Nakabuye $^{1} \cdot$ Abia Katimbo $^{1}$. \\ Yufeng $\mathrm{Ge}^{3} \cdot$ Trenton E. Franz ${ }^{4} \cdot$ Xin Qiao $^{5} \cdot$ Derek M. Heeren $^{3}$
}

Received: 14 September 2019 / Accepted: 22 June 2020 / Published online: 20 August 2020

○) Springer-Verlag GmbH Germany, part of Springer Nature 2020

\begin{abstract}
Crop nitrogen $(\mathrm{N})$ status is known to affect crop water status and crop water use. To investigate further the $\mathrm{N}$ effects on soil water changes and on canopy temperature, three water levels $\times$ four $\mathrm{N}$ levels were imposed on two growing seasons of maize in west central Nebraska, USA. Soil water changes were measured using a neutron probe, whereas canopy temperature was measured using infrared thermometers on a ground-based mobile platform. At all water levels, soil water losses over monthlong intervals were generally greater as $\mathrm{N}$ levels increased. Given equal water levels, early afternoon canopy temperatures were usually lower with higher $\mathrm{N}$ levels, but no trend or even the opposite trend was occasionally observed. Jointly considering canopy reflectance and soil water depletion shows potential to explain much of the variation in estimated instantaneous water use among plots. However, determining the relative contributions of the canopy and soil factors on a particular day may require season-to-date knowledge of the crop. Further research on assimilating such sensor data for a combined stress coefficient would improve crop modeling and irrigation scheduling when variable water sufficiency and variable $\mathrm{N}$ sufficiency are simultaneously significant.
\end{abstract}

\section{Introduction}

Water and nitrogen $(\mathrm{N})$ are known to be strongly interdependent for crop production (Gheysari et al. 2009; MansouriFar et al. 2010). Specifically, crop $\mathrm{N}$ uptake is tightly linked to water sufficiency (Albrizio et al. 2010) because root water uptake plays a dominant role in bringing dissolved $\mathrm{N}$ to the plant. A scarcity of water can, thus, reduce $\mathrm{N}$ access besides inducing water stress (González-Dugo et al. 2010). At the

Daran R. Rudnick

daran.rudnick@unl.edu

1 West Central Research and Extension Center, University of Nebraska-Lincoln, North Platte, NE 69101, USA

2 Water Management and Systems Research Unit, USDA-ARS, Fort Collins, CO 80526, USA

3 Department of Biological Systems Engineering, University of Nebraska-Lincoln, Lincoln, NE 68583, USA

4 School of Natural Resources, University of Nebraska-Lincoln, Lincoln, NE 68583, USA

5 Panhandle Research and Extension Center, University of Nebraska-Lincoln, Scottsbluff, NE 69361, USA

6 National Center for Alluvial Aquifer Research, Mississippi State University, Leland, MS 38756, USA same time, an excess of water can leach dissolved $\mathrm{N}$ out of the root zone and/or promote volatilization losses of soil $\mathrm{N}$ (Spalding et al. 2001). Likewise, crop water use is tightly linked to $\mathrm{N}$ sufficiency because $\mathrm{N}$ serves as an essential part of myriad plant constituents and therefore influences both plant growth and water regulation (Saneoka et al. 2004). A scarcity of $\mathrm{N}$ leads not only to a smaller transpiring leaf area (Pandey et al. 2000) but also to lower stomatal conductance on those leaves (Shangguan et al. 2000). In the opposite extreme, an excess of $\mathrm{N}$ can cause undesirably high water use for some crops particularly during the vegetative period of a dry growing season (van Herwaarden et al. 1998).

The close interactions between water and $\mathrm{N}$ should not be ignored when practicing sensor-based management of irrigation and $\mathrm{N}$ fertilizer. By collecting and reacting to soil and/or plant measurements, sensor-based management can adapt to spatiotemporal variability in the optimal amount and timing of input application. This responsiveness can improve farm profitability and environmental stewardship as compared with the practice of always applying a fixed rate on a fixed schedule on every field. However, the ability to distinguish water stress from $\mathrm{N}$ stress becomes crucial in the potential presence of both stresses. For example, suppose irrigation is triggered by comparing soil water changes and/ 
or canopy temperature in a particular field against a water sufficient reference. Irrigation would be wastefully applied if $\mathrm{N}$ stress-rather than water stress-limits crop water use and consequently slows down soil water decline and raises canopy temperature.

With such possible confounding in mind, this study targets two objectives. First, it aims to contribute to greater understanding of $\mathrm{N}$ effects on soil water changes (Ogola et al. 2002; Lenka et al. 2009; Rudnick and Irmak 2014a, b; Rudnick et al. 2017) and on canopy temperature (Seligman et al. 1983; Nielsen and Halvorson, 1991; Peñuelas et al. 1996; Tilling et al. 2007; Fois et al. 2009; Mon et al. 2016; Carroll et al. 2017; Yang et al. 2018) in corn (Zea mays L.) under different water levels. Soil water loss and canopy temperature minus air temperature were quantified for corn receiving various water $\times N$ treatments. Second, the study aims to explore the implications of variable $\mathrm{N}$ sufficiency for the interpretation of soil water and canopy temperature measurements. A combined stress factor incorporating both canopy status and soil status was preliminarily evaluated on its feasibility to account for the joint impact of water stress and $\mathrm{N}$ stress on corn water use. The ultimate goal is integrated thinking about and conjunctive management of water and $\mathrm{N}$.

\section{Methods}

\section{Experiment description}

This study analyzed 2017 and 2018 data from corn grown at the University of Nebraska-Lincoln West Central Research and Extension Center in North Platte, NE, USA. The soil is a loam with approximately $2 \%$ organic matter in the top $0.2 \mathrm{~m}$ (Ward Laboratories, Kearney, NE, USA). The study area had received full $\mathrm{N}$ management for corn during the three prior growing seasons (i.e., 2014, 2015, and 2016). For the study, corn seed blend DeKalb 61-54 (Bayer Crop Science, St. Louis, MO, USA) was planted into corn residue at 81,500 seeds ha $^{-1}$ with $0.76-\mathrm{m}$ row spacing on 8 May 2017 and on 27 April 2018. Crop rows were concentric with the pivot point of the center pivot irrigation system. No tillage was performed during the study. Each treatment combination (Table 1) of three water levels $\times$ four $\mathrm{N}$ levels was imposed onto the same set of four plots in 2017 as in 2018 . Three replicates were included in the present analyses.

The water levels were (1) no irrigation (NI), (2) alternate irrigation (AI), and (3) full irrigation (FI). Alternate irrigation was imposed by withholding every second application of full irrigation. Scheduled based on the highest $\mathrm{N}$ level, full irrigation sought to maintain a moderate rainfall allowance during the middle of the growing season and then to extract progressively more soil water as the corn approached maturity (Kranz et al. 2008).

The N levels were (1) 0, (2) 67, (3) 202, and (4) $269 \mathrm{~kg} \mathrm{ha}^{-1}$ of intentionally added N. Regardless of the level, half of the seasonal rate was applied as urea ammonium nitrate (UAN; 32-0-0) using a double-coulter liquid applicator before planting. The remaining half was applied as UAN using the same applicator around V4 (the corn growth stage system of Abendroth et al. (2011) is used throughout this paper). The two UAN application dates were 5 May and 12 June in 2017 and 19 April and 31 May in 2018. Unintentionally added N (Table 1) originated from at-plant ammonium polyphosphate $\left(47 \mathrm{~L} \mathrm{ha}^{-1}\right.$ of 10-34-0) and from irrigation water (1.5 ppm N; Ward Laboratories, Kearney, NE, USA).
Table 1 The 12 treatment combinations of three water levels $\times$ four nitrogen levels in this study

\begin{tabular}{|c|c|c|c|c|c|c|c|c|}
\hline \multirow[t]{2}{*}{ Water level } & \multirow[t]{2}{*}{ Nitrogen level } & \multicolumn{2}{|c|}{$\begin{array}{l}\text { Seasonal irri- } \\
\text { gation }(\mathrm{mm} \\
\left.\text { year }^{-1}\right)\end{array}$} & \multicolumn{2}{|c|}{$\begin{array}{l}\text { Intentional N } \\
\text { addition }(\mathrm{kg} \\
\left.\mathrm{ha}^{-1} \text { year }^{-1}\right)\end{array}$} & \multicolumn{3}{|c|}{$\begin{array}{l}\text { Unintentional } \mathrm{N} \text { addition }\left(\mathrm{kg} \mathrm{ha}^{-1}\right. \\
\text { year }\end{array}$} \\
\hline & & 2017 & 2018 & Preplant & V4 & At-plant & 2017 Irrig & 2018 Irrig \\
\hline \multirow[t]{4}{*}{ No irrigation } & $0 \mathrm{~kg} \mathrm{ha}^{-1}$ & 0 & 0 & 0 & 0 & 7 & 0 & 0 \\
\hline & $67 \mathrm{~kg} \mathrm{ha}^{-1}$ & & & 34 & 34 & & & \\
\hline & $202 \mathrm{~kg} \mathrm{ha}^{-1}$ & & & 101 & 101 & & & \\
\hline & $269 \mathrm{~kg} \mathrm{ha}^{-1}$ & & & 135 & 135 & & & \\
\hline \multirow[t]{4}{*}{ Alternate irrigation } & $0 \mathrm{~kg} \mathrm{ha}^{-1}$ & 147 & 102 & 0 & 0 & 7 & 2 & 2 \\
\hline & $67 \mathrm{~kg} \mathrm{ha}^{-1}$ & & & 34 & 34 & & & \\
\hline & $202 \mathrm{~kg} \mathrm{ha}^{-1}$ & & & 101 & 101 & & & \\
\hline & $269 \mathrm{~kg} \mathrm{ha}^{-1}$ & & & 135 & 135 & & & \\
\hline \multirow[t]{4}{*}{ Full irrigation } & $0 \mathrm{~kg} \mathrm{ha}^{-1}$ & 295 & 203 & 0 & 0 & 7 & 4 & 3 \\
\hline & $67 \mathrm{~kg} \mathrm{ha}^{-1}$ & & & 34 & 34 & & & \\
\hline & $202 \mathrm{~kg} \mathrm{ha}^{-1}$ & & & 101 & 101 & & & \\
\hline & $269 \mathrm{~kg} \mathrm{ha}^{-1}$ & & & 135 & 135 & & & \\
\hline
\end{tabular}




\section{Data collection and processing}

Soil water was measured using neutron moisture meters (NMM), specifically a CPN 503 Elite Hydroprobe (InstroTek, Concord, CA, USA) in 2017 and a CPN 503DR (InstroTek, Concord, CA, USA) in 2018. The 503 Elite Hydroprobe had been cross calibrated locally $\left(R^{2}=0.994\right.$; resubstitution root mean square error $($ RMSE $)=0.004$ $\mathrm{m}^{3} \mathrm{~m}^{-3}$ ) to the 503DR, which in turn had been thermogravimetrically calibrated locally $\left(R^{2}=0.977\right.$; resubstitution $\mathrm{RMSE}=0.010 \mathrm{~m}^{3} \mathrm{~m}^{-3}$ ). One aluminum access tube was installed in a crop row near the center of each plot. On each NMM measurement date, one 15-s count by the 503 Elite HydroProbe or one 16-s count by the 503DR was taken at $0.15,0.46,0.76,1.07$, and $1.37 \mathrm{~m}$ depths. Each NMM count was assumed to represent the 0.30 -m interval centered on the measurement depth. Then, the NMM counts were divided by the average of the two standard counts on that measurement date and then converted into volumetric water content $\left(\theta_{\mathrm{v}}\right)$ according to the local gauge specific calibration equations.

Soil water depletion on each measurement date was calculated by subtracting $\theta_{\mathrm{v}}$ on that date from field capacity. In this study, field capacity was approximated as $\theta_{\mathrm{v}}$ on 8 June 2017. In contrast, soil water loss between two measurement dates was calculated by subtracting $\theta_{\mathrm{v}}$ on the later date from $\theta_{\mathrm{v}}$ on the earlier date. If $\mathrm{N}$ levels affected soil water loss to a noteworthy extent, the effects should be noticeable over intervals of about a month or longer with minimal nonuniform (i.e., unequal among treatments) deep percolation. Therefore, soil water loss over two such intervals in 2017 and over three such intervals in 2018 were compared among treatments with different $\mathrm{N}$ levels but the same water level. The first interval of 2017 spanned from 8 June (1st NMM measurement in 2017; two days after the start of V4) to 28 July (3rd NMM measurement in 2017; two days after the start of R1) and included $58 \mathrm{~mm}$ of rain. The second interval of 2017 spanned from 25 August (7th NMM measurement in 2017; two days after the start of R4) to 22 September (11th NMM measurement in 2017; $60 \%$ milk line) and included $133 \mathrm{~mm}$ of rain. The first interval of 2018 spanned from 2 June (1st NMM measurement in 2018; the start of V4) to 4 July (5th NMM measurement in 2017; the start of V13) and included $94 \mathrm{~mm}$ of rain. The second interval of 2018 spanned from 4 July to 9 August (10th NMM measurement in 2018; one day before the start of R4) and included $70 \mathrm{~mm}$ of rain. The third interval of 2018 spanned from 9 August to 13 September (13th NMM measurement in 2018; one day before R6) and included $41 \mathrm{~mm}$ of rain.

Canopy temperature $\left(T_{\mathrm{c}}\right)$ was measured using four SI-1H1 infrared thermometers (IRT; Apogee Instruments, Logan, UT, USA) under clear skies during early afternoons. Two IRTs - each oriented $60^{\circ}$ from nadir - were attached to each end of a tractor mounted boom. On each IRT measurement date, the tractor traveled along alleys parallel with the crop rows, so that every plot was measured by the left pair of the IRTs exactly once and by the right pair of IRTs exactly once. Throughout 2017, all IRTs were positioned at a height of $2.7 \mathrm{~m}$ above ground and were pointed parallel to the boom and away from the tractor in the middle. Throughout 2018, all IRTs were still pointed parallel to the boom, but one IRT in each pair pointed towards the tractor, while the other IRT in that pair pointed away from the tractor. All IRTs were positioned at a height of $2.3 \mathrm{~m}$ above ground on 28 June 2018 and were raised to $2.7 \mathrm{~m}$ above ground for the remainder of 2018.

On each IRT measurement date, the same tractor mounted boom also measured canopy reflectance using Crop Circle ACS-430 active optical sensors (Holland Scientific, Lincoln, NE, USA) that viewed the same general areas as the IRTs. The ACS-430s were oriented nadir and were placed $0.2 \mathrm{~m}$ higher than the IRTs. Throughout 2017, one ACS-430 was attached to each end of the boom and was positioned above an interrow. Throughout 2018, two ACS-430s were attached to each end of the boom, and all ACS-430 were positioned above crop rows on 28 June and 3 July 2018 but were positioned above interrows for the remainder of 2018 to minimize the viewing of tassels (Shaver et al. 2017).

To georeference the on-the-go $T_{\mathrm{c}}$ and reflectance measurements, a Geo7x global positioning system (GPS) receiver (Trimble Inc., Sunnyvale, CA, USA) was attached to the tractor in 2017. In 2018, however, a GPS receiver that was designed and donated by Holland Scientific (Lincoln, NE, USA) performed this task instead. The approximate number of $T_{\mathrm{c}}$ measurements by each of the four IRTs in each plot on each measurement date was 9 in 2017 and 28 in 2018. For each plot, $T_{\mathrm{c}}$ measurements were first averaged by IRT, and then those four IRT averages were finally averaged to obtain one $T_{\mathrm{c}}$ value to represent that plot on that measurement date. On the other hand, the approximate number of reflectance measurements in each plot on each measurement date was 273 by each of the two ACS-430s in 2017 and 71 by each of the four ACS-430s in 2018. For each plot, the median value of the normalized difference vegetation index (NDVI) was first computed for each ACS-430, and then those two or four ACS-430 medians were finally averaged to obtain one NDVI value to represent that plot on that measurement date. The relative NDVI of a plot on a given measurement date was defined as the ratio between the NDVI value of the plot on the given measurement date and the maximum NDVI value among all plots on the same measurement date.

When canopy cover is high, $T_{\mathrm{c}}$ can serve as an approximation of the aerodynamic temperature for sensible heat flux (Kustas et al. 2007). Thus, crop evapotranspiration can be estimated based on surface energy balance relations if $T_{\mathrm{c}}$ and meteorological variables were known. The Nebraska State Climate Office (https://nsco.unl.edu) supplied 5-min weather 
data from its North Platte 3SW Alpha station $1.7 \mathrm{~km}$ away in 2017 and supplied 1-min weather data from its North Platte 3SW Beta station $1.1 \mathrm{~km}$ away in 2018. Because weather conditions remained similar within each IRT measurement period, the averages of the meteorological variables during an IRT measurement period (Table 2) were assumed to represent that period. These average values were combined with the aforementioned $T_{\mathrm{c}}$ values to generate a rudimentary single source (a.k.a. "big leaf") estimate of crop evapotranspiration (ET; Eq. 1) for each plot during each IRT measurement period. Equation 1 in this study is a rearrangement of Eqs. 1-2 in Jackson et al. (1988).

$\mathrm{ET}=\left[R_{\mathrm{n}}-G-\rho c_{\mathrm{p}}\left(T_{\mathrm{c}}-T_{\mathrm{a}}\right) / r_{\mathrm{a}}\right] / \lambda$,

where $\mathrm{ET}=$ crop evapotranspiration $\left(\mathrm{kg} \mathrm{m}^{-2} \mathrm{~s}^{-1}\right), R_{\mathrm{n}}=$ net radiation $\left(\mathrm{W} \mathrm{m}^{-2}\right), G=$ soil heat flux $\left(\mathrm{W} \mathrm{m}^{-2}\right), \rho=$ density of air $\left(\mathrm{kg} \mathrm{m}^{-3}\right), c_{\mathrm{p}}=$ heat capacity of air $\left(\mathrm{J} \mathrm{kg}^{-1}{ }^{\circ} \mathrm{C}^{-1}\right)$, $T_{\mathrm{c}}=$ canopy temperature $\left({ }^{\circ} \mathrm{C}\right), T_{\mathrm{a}}=$ air temperature $\left({ }^{\circ} \mathrm{C}\right)$, $r_{\mathrm{a}}=$ aerodynamic resistance $\left(\mathrm{s} \mathrm{m}^{-1}\right)$, and $\lambda=$ latent heat of water vaporization $\left(\mathrm{J} \mathrm{kg}^{-1}\right)$.

Wind speed over the corn crop was approximated using Eq. 13 in Allen and Wright (1997) and then was entered into Eq. 9 in Jackson et al. (1988) for $r_{\mathrm{a}}$. All other variables in Eq. 1 were computed according to the hourly short reference procedures of the Task Committee on Standardization of Reference Evapotranspiration (2005). The relative ET of a plot during a given measurement period was defined as the ratio between the ET value of the plot during the given measurement period (Eq. 1) and the maximum ET value among all plots during the same measurement period. Just like the Crop Water Stress Index (Jackson et al. 1988), Eq. 1 assumes that relative ET is a linear function of $T_{\mathrm{c}}$.

\section{Statistical analysis}

For sub-seasonal analyses, all statistical computations were performed in Excel 2010 (Microsoft Corporation, Redmond, WA, USA). Correlation coefficients were calculated using the built-in function CORREL. Coefficients of determination $\left(R^{2}\right)$ were calculated as 1 - (residual sum of squares)/(total sum of squares). Regression was conducted using the Solver add-in to minimize error sum of squares.

The interreplicate variability in sub-seasonal results was considered to be too large for formal statistical procedures. Therefore, a linear mixed model was fitted independently to (1) the total soil water loss across all two intervals in 2017 (8 June-28 July and 25 August-22 September; see previous subsection for details), (2) the total soil water loss across all three intervals in 2018 (2 June-4 July, 4 July-9 August, and 9 August-13 September; see previous subsection for details), (3) the average relative ET across all eight measurement dates in 2017 (Table 2), and (4) the average relative ET across all eight measurement dates in 2018 (Table 2), respectively. The fixed effects were water level (as a categorical variable), $\mathrm{N}$ level (as a continuous variable), and water level $\times \mathrm{N}$ level. The random effects for the strip plot experimental design of this study were block, block $\times$ water level, block $\times \mathrm{N}$ level, and residual error. Denominator degrees of freedom were computed according to the Kenward-Roger's
Table 2 Growth stage, start and end times, and average weather conditions-air temperature $\left(T_{\mathrm{a}}\right)$, relative humidity $(\mathrm{RH})$, wind speed $(u)$, solar radiation $\left(R_{\mathrm{S}}\right)$, and short reference evapotranspiration $\left(\mathrm{ET}_{\mathrm{o}}\right)$ corresponding to canopy temperature measurement periods

\begin{tabular}{lllllllll}
\hline $\begin{array}{l}\text { Measurement } \\
\text { Date }\end{array}$ & $\begin{array}{l}\text { Growth } \\
\text { Stage }\end{array}$ & $\begin{array}{l}\text { Start time } \\
\text { (h after solar noon) }\end{array}$ & $\begin{array}{l}\text { End time } \\
\left({ }^{\circ} \mathrm{C}\right)\end{array}$ & $\begin{array}{l}T_{\mathrm{a}} \\
(\%)\end{array}$ & $\begin{array}{l}\mathrm{RH} \\
\left(\mathrm{m} \mathrm{s}^{-1}\right)\end{array}$ & $\begin{array}{l}R_{\mathrm{s}} \\
\left(\mathrm{W} \mathrm{m}^{-2}\right)\end{array}$ & $\begin{array}{l}\mathrm{ET}_{\mathrm{o}} \\
\left(\mathrm{mm} \mathrm{h}^{-1}\right)\end{array}$ \\
\hline 24 Jul 2017 & V16 & 0.7 & 1.5 & 36.6 & 17.7 & 5.9 & 767 & 0.90 \\
31 Jul 2017 & R1 & 1.8 & 2.7 & 30.5 & 41.5 & 1.5 & 772 & 0.61 \\
11 Aug 2017 & R2 & 0.7 & 1.5 & 25.2 & 47.2 & 2.1 & 758 & 0.56 \\
18 Aug 2017 & R3 & 2.0 & 2.8 & 31.5 & 29.2 & 1.0 & 691 & 0.54 \\
19 Aug 2017 & R3 & 0.7 & 1.5 & 33.3 & 40.0 & 4.8 & 716 & 0.70 \\
30 Aug 2017 & R4 & -0.3 & 0.4 & 30.0 & 33.8 & 4.1 & 779 & 0.69 \\
13 Sep 2017 & R5.35 & 1.6 & 2.3 & 33.4 & 26.2 & 2.4 & 537 & 0.52 \\
21 Sep 2017 & R5.55 & 2.3 & 3.0 & 34.9 & 12.8 & 6.2 & 404 & 0.68 \\
28 Jun 2018 & V10 & 2.0 & 2.6 & 34.0 & 49.7 & 1.9 & 643 & 0.56 \\
3 Jul 2018 & V12 & 2.2 & 2.8 & 32.3 & 41.6 & 3.5 & 556 & 0.55 \\
9 Jul 2018 & V14 & 2.3 & 2.9 & 33.6 & 28.7 & 3.0 & 576 & 0.58 \\
11 Jul 2018 & V15 & 2.3 & 2.8 & 34.9 & 27.7 & 3.8 & 577 & 0.63 \\
19 Jul 2018 & R1 & 1.2 & 1.7 & 32.8 & 40.5 & 1.1 & 770 & 0.62 \\
25 Jul 2018 & R2 & 1.5 & 2.1 & 28.5 & 54.4 & 1.5 & 814 & 0.61 \\
2 Aug 2018 & R3 & 1.4 & 2.0 & 33.2 & 34.5 & 5.1 & 675 & 0.70 \\
11 Aug 2018 & R4 & 1.3 & 1.9 & 33.1 & 22.6 & 3.3 & 650 & 0.65 \\
\hline
\end{tabular}

Local time at solar noon was provided by https://www.esrl.noaa.gov/gm/grad/solcalc/; weather data was provided by https://nsco.unl.edu 


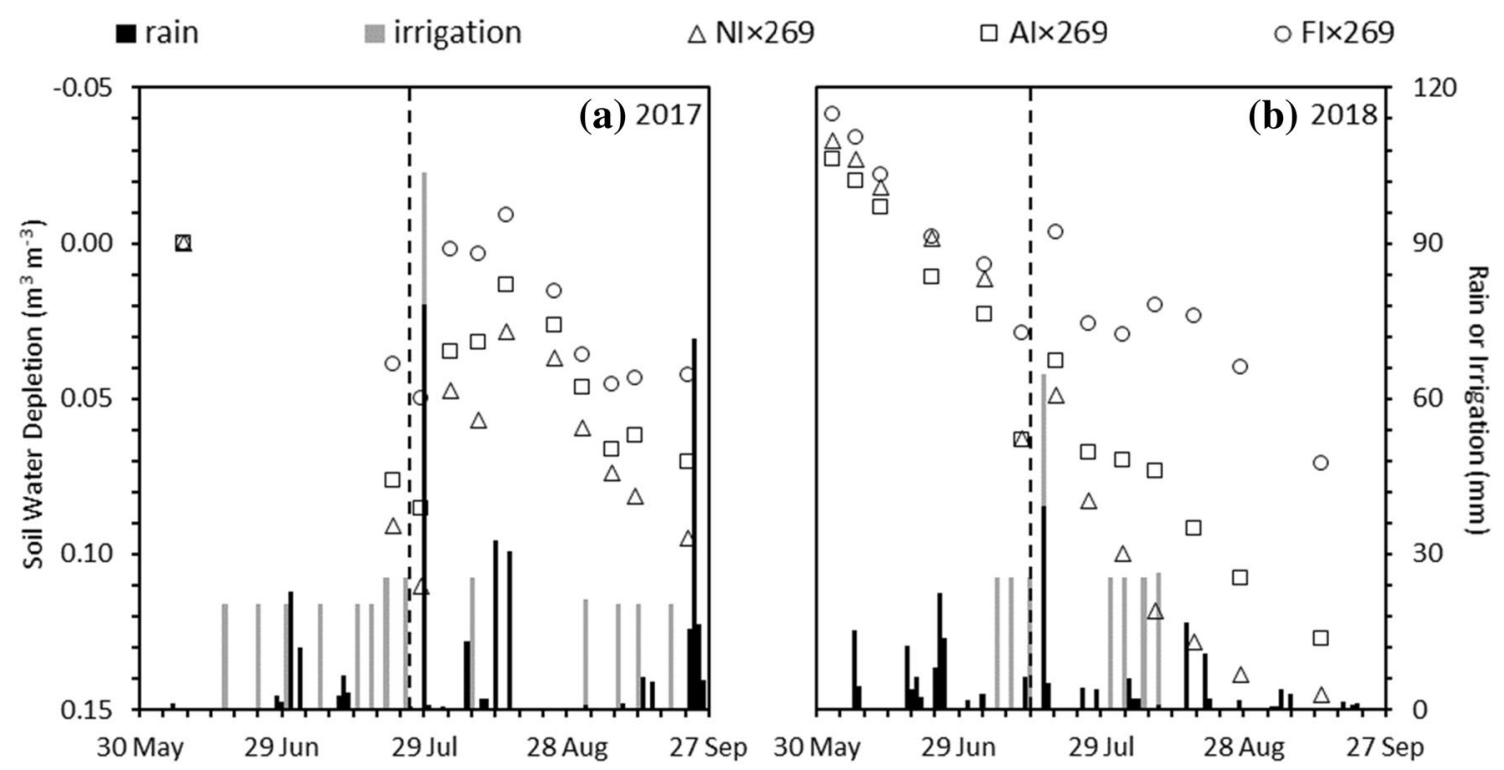

Fig. 1 Soil water depletion (i.e., deficit below field capacity) within the top $1.5 \mathrm{~m}$-averaged across three replicates-of the no irrigation $(\mathrm{NI}) \times 269 \mathrm{~kg} \mathrm{ha}^{-1}$ fertilizer N, alternate irrigation $(\mathrm{AI}) \times 269 \mathrm{~kg} \mathrm{ha}^{-1}$ fertilizer $\mathrm{N}$, and full irrigation $(\mathrm{FI}) \times 269 \mathrm{~kg} \mathrm{ha}^{-1}$ fertilizer $\mathrm{N}$ treat-

method. These seasonal analyses were performed using $\mathrm{R}$ 4.0.0 (R Core Team 2020) with packages lme4 1.1-23 (Bates et al. 2015), lmerTest 3.1-2 (Kuznetsova et al. 2017), and pbkrtest 0.4-8.6 (Halekoh and Højsgaard 2014).

\section{Results and discussion}

\section{Soil water changes}

NMM measurements in 2017 were concentrated mostly in the latter part of the growing season (Fig. 1a). Nonetheless, the measurements captured two distinct drying cycles that were separated by a wet period from the end of July to the middle of August, during which a series of heavy rains may have caused deep percolation in plots with smaller soil water depletions. NMM measurements in 2018 were spread out more evenly and described one largely continuous drying cycle (Fig. 1b). The three water levels were differentiated by soil water depletion in both years after the commencement of irrigation. For the remainder of each growing season, soil water depletion generally stayed smaller at higher water levels. Positive soil water depletion indicated that volumetric water content was below field capacity, whereas negative soil water depletion indicated that volumetric water content was above field capacity.

Irrigation clearly impacted soil water loss, which decreased consistently with higher water levels (Fig. 2). The only exception was the first interval of 2018 (Fig. 2c), ments during two growing seasons; the beginning of R1 is marked by a dashed vertical line, and daily amounts of rain and full irrigation are indicated by stacked (not overlaying) bars

during which no irrigation occurred. Positive soil water loss indicated a net decrease in volumetric water content during the interval, whereas negative soil water loss indicated a net increase in volumetric water content during the interval. Given the same water level, higher $\mathrm{N}$ levels were generally associated with larger soil water loss. In 43 out of 45 comparisons within reps and water levels (except NI rep 3 in the first interval of 2017 and except NI rep 2 in the third interval of 2018), soil water loss was larger at the highest than the lowest $\mathrm{N}$ level. Pooling together all replicates and then grouping by the three water levels and by the five intervals, the 15 correlation coefficients between seasonal $\mathrm{N}$ rate and soil water loss were all positive. These values ranged from 0.13 (NI in the first interval of 2018) to 0.86 (AI in the second interval of 2018), and the median was 0.61 .

Given the short-term nature of the treatments, hydraulic conductivity should not be different among $\mathrm{N}$ levels. Higher $\mathrm{N}$ levels are, thus, not expected to decrease the infiltration of rain and irrigation. Instead, the observed differences in soil water loss among $\mathrm{N}$ levels given the same water level resulted most likely from differences in crop evapotranspiration (ET). Both Ogola et al. (2002) and Lenka et al. (2009) made this assumption in their interpretation of soil water data to estimate ET by entirely ignoring runoff and deep percolation. With and without irrigation, ET increased with $\mathrm{N}$ addition in all three experiments of Ogola et al. (2002). At each of three water levels, ET increased monotonically with four increasing $\mathrm{N}$ levels in all four growing seasons of 


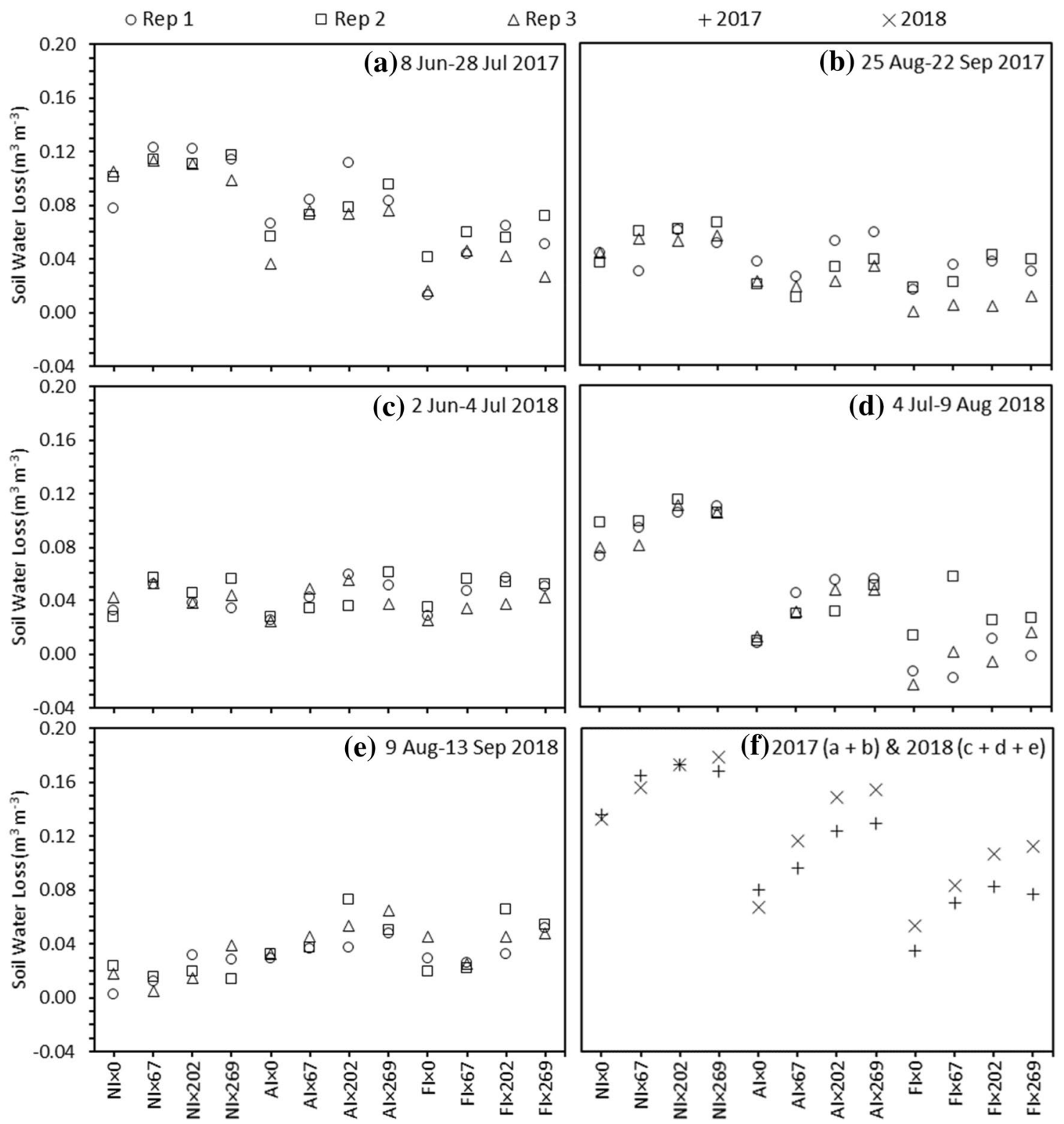

Fig. 2 Soil water loss (i.e., net reduction in soil water content) within the top $1.5 \mathrm{~m}$ for each water (i.e., no irrigation (NI), alternate irrigation $(\mathrm{AI})$, or full irrigation $(\mathrm{FI})) \times$ nitrogen $\left(0,67,202\right.$, or $269 \mathrm{~kg} \mathrm{ha}^{-1}$ fertilizer $\mathrm{N}$ ) treatment during six intervals; the treatment average

Lenka et al. (2009). The findings of this study are in broad agreement with the findings of these two studies.

The $\mathrm{N}$ impact on ET seemed to be present to some degree in both the vegetative (Fig. 2a, c) and the reproductive (Fig. 2b, e) periods of this study. In contrast, during the reproductive but not the vegetative period, Rudnick et al. (2017) found a pattern of higher ET with increasing N levels under the same water level. Results like those of Rudnick et al. (2017) should not be misinterpreted to claim that the $\mathrm{N}$ impact on ET begins abruptly at flowering. First, in cases including Rudnick et al. (2017), most of the seasonal sums of the two 2017 intervals (subfigures $\mathbf{a}$ and $\mathbf{b}$ ) and the treatment average sums of the three 2018 intervals (subfigures $\mathbf{c}-\mathbf{e}$ ) are presented in subfigure $\mathbf{f}$

$\mathrm{N}$ fertilizer rate was applied no later than the mid vegetative period. Much of the vegetative period corresponded consequently to maximum availability of fertilizer $\mathrm{N}$ and mineralized $\mathrm{N}$ and to minimum $\mathrm{N}$ requirements and minimum daily ET rates. Therefore, differences in canopy and in ET could start small and be difficult to detect until the differences became larger as the season progressed. Second, whenever a higher $\mathrm{N}$ level leads to a larger and/or more active canopy, the consequent increase in transpiration could be offset at least in part by a decrease in evaporation (Rudnick et al. 2017). ET could be ultimately similar across N 
levels especially if the surface is frequently wetted by rain or irrigation. In general, how the $\mathrm{N}$ impact on ET varies throughout the growing season depends on the temporal distributions of $\mathrm{N}$ addition, mineralization/immobilization, and loss relative to crop $\mathrm{N}$ demand. Because these distributions could differ among years and locations, sweeping claims about the lack of $\mathrm{N}$ impact on ET during particular growth stages should not be made rashly.

Differences in soil water loss among $\mathrm{N}$ levels were greater for 2018 than for 2017 (Fig. 2f). This contrast could be attributed to previous management and to weather. Following years of full $\mathrm{N}$ management and then experiencing higher spring soil temperatures, the initial availability of soil inorganic $\mathrm{N}$ would be relatively high in 2017-the year with smaller differences in soil water loss. On the other hand, following a year of $\mathrm{N}$ treatments and then experiencing lower spring soil temperatures, the initial availability of soil inorganic N would be relatively low in 2018 - the year with larger differences in soil water loss.

Interestingly, the smallest spread in soil water loss between the lowest and highest $\mathrm{N}$ levels was under no irrigation while the largest spread was under alternate irrigation (Fig. 2f). In the absence of irrigation, water scarcity was a major limiting factor and lessened the $\mathrm{N}$ impact on $\mathrm{ET}$. Alternate irrigation, however, eliminated much of the water stress, so ET was relatively free to increase with increasing $\mathrm{N}$ level. Although full irrigation eliminated water stress to an even greater extent, the full irrigation $\times 0 \mathrm{~kg} \mathrm{ha}^{-1}$ fertilizer $\mathrm{N}$ treatment was most prone to deep percolation among all treatments. This particular treatment was subjected to an irrigation schedule tailored to the full irrigation $\times 269 \mathrm{~kg} \mathrm{ha}^{-1}$ fertilizer $\mathrm{N}$ treatment even while experiencing lower ET. Any deep percolation that occurred at the lowest $\mathrm{N}$ level but not the highest $\mathrm{N}$ level would increase soil water loss of the lowest $\mathrm{N}$ level and, thus, reduce the spread in soil water loss.

\section{Canopy temperature}

Whereas soil water changes summarized the net $\mathrm{N}$ impact on ET over longer intervals at particular points in space, $T_{\mathrm{c}}$ captured the spatially averaged $\mathrm{N}$ impact on ET at particular snapshots in time. $T_{\mathrm{c}}$ was jointly influenced by multiple factors including weather conditions (Table 2), water level, and $\mathrm{N}$ level. Lower water levels were associated not only with warmer $T_{\mathrm{c}}$ but also with larger interreplicate variability in $T_{\mathrm{c}}$ (Fig. 3). The latter phenomenon has been reported by others including Clawson and Blad (1982), González-Dugo et al. (2006), and Han et al. (2016). At the majority of measurement times, $T_{\mathrm{c}}$ decreased with increasing $\mathrm{N}$ level. This trend was usually stronger at the measurement times in 2018 (i.e., the year with more severe $\mathrm{N}$ stress; Fig. 3i-p) than at the measurement times in 2017 (i.e., the year with milder $\mathrm{N}$ stress; Fig. 3a-h). Pooling together all replicates and then grouping by the three water levels and by the eight intervals, the mean \pm sample standard deviation of 24 correlation coefficients between seasonal $\mathrm{N}$ rate and $T_{\mathrm{c}}$ was $-0.13 \pm 0.27$ and $-0.62 \pm 0.27$ in 2017 and 2018, respectively. Whether using shielded thermocouples (Seligman et al. 1983), thermal cameras (Tilling et al. 2007), or IRTs (Peñuelas et al. 1996; Fois et al. 2009; Mon et al. 2016), a negative association between $T_{\mathrm{c}}$ and $\mathrm{N}$ level has been widely noted by various studies.

$\mathrm{N}$ can impact $T_{\mathrm{c}}$ through at least three mechanisms. The first mechanism is that lower $\mathrm{N}$ levels can reduce the size and/or activity of canopies (Seligman et al. 1983; Nielsen and Halvorson, 1991; Pandey et al. 2000; Tilling et al. 2007). If ET is limited by the scarcity of active leaf area, the canopy could become hotter because of reduced evaporative cooling. Furthermore, when canopies are very sparse, even off nadir IRTs cannot exclude the typical hotter background (e.g., soil, residue, mulch) from their fields of view and will consequently make positively biased measurements. This first mechanism was likely at play in 2018 , when more severe $\mathrm{N}$ stress altered canopies drastically. As indicated by canopy reflectance (see next subsection), the disparity between canopies receiving the lowest $\mathrm{N}$ level and those receiving the highest $\mathrm{N}$ level remained vast despite partial narrowing during the late vegetative and early reproductive growth stages. In contrast, the first mechanism may be less relevant in 2017 because any lag in canopy development due to milder $\mathrm{N}$ stress was largely caught up by the beginning of the reproductive period. The second mechanism is that lower $\mathrm{N}$ levels can reduce stomatal conductance (Peñuelas et al. 1996; Shangguan et al. 2000; Fois et al. 2009; Yang et al. 2018) and modify other leaf properties and/or behaviors (Saneoka et al. 2004). Fois et al. (2009) isolated the role of this second mechanism by detecting even after irrigation $T_{\mathrm{c}}$ differences using IRTs that viewed canopies only and by detecting leaf conductance differences using a viscous flow porometer. With decreasing N level, Yang et al. (2018) found increasing leaf temperature using a handheld thermal camera and found decreasing stomatal conductance using a portable infrared gas analyzer. The third mechanism is that lower $\mathrm{N}$ levels can shrink the rooting volume (Nielsen and Halvorson, 1991). Because less stored soil water becomes accessible, the $\mathrm{N}$ stressed plants are more prone to water stress. In both 2017 and 2018, the involvement of the second and third mechanisms cannot be ruled out.

Not every water level at every measurement time witnessed the same universal relationship between $\mathrm{N}$ levels and $T_{\mathrm{c}}$ (Fig. 3). In some instances, $T_{\mathrm{c}}$ exhibited no discernable trend with increasing $\mathrm{N}$ levels. Such results might be attributed at least partially to spatial variability in background (i.e., residual and readily mineralized) $\mathrm{N}$. Wherever high background $\mathrm{N}$ counteracted low $\mathrm{N}$ levels and wherever low background $\mathrm{N}$ counteracted high $\mathrm{N}$ levels, differences in 

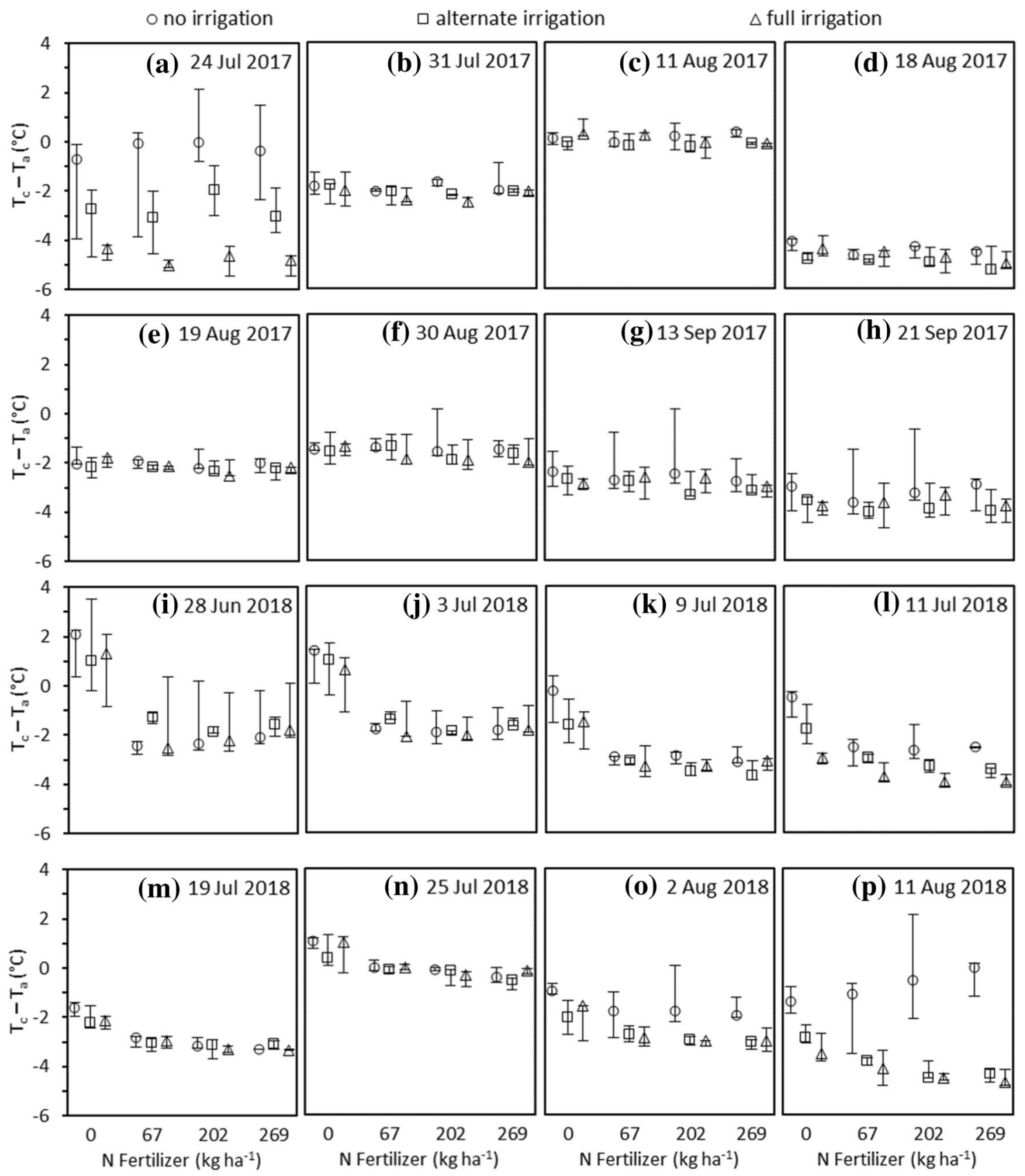

Fig. 3 Canopy temperature minus air temperature $\left(T_{\mathrm{c}}-T_{\mathrm{a}}\right)$ for each water $\times$ nitrogen treatment during 16 measurement times; the median of three replicates is indicated by a symbol, while the two extrema are indicated by error bars

$T_{\mathrm{c}}$ among $\mathrm{N}$ levels would be blurred. This blurring may be especially prevalent in 2017, which followed years of full $\mathrm{N}$ management and witnessed milder $\mathrm{N}$ stress.

At odds with the previously cited literature, Carroll et al. (2017) claimed that canopy temperature and Crop Water Stress Index are unaffected by $\mathrm{N}$ treatments. However, both the greenhouse and field components of Carroll et al. (2017) measured the temperature of "an unshaded area of the newest, fully expanded leaf" using a handheld thermal camera.
Such temperature measurements and the derived Crop Water Stress Index values can be different than those obtained from above canopy IRTs, aerial thermal cameras, and satellite longwave radiometers. The three latter types of sensors do not exclude older leaves (which tend to be more heavily affected by $\mathrm{N}$ stress) within their fields of view but instead capture an aggregate of sunlit leaves, shaded leaves, and perhaps even the ground below (whose contribution tends to be larger with sparser canopies resulting from $\mathrm{N}$ stress). 
Table 3 Restricted maximum likelihood estimates of the slope of soil water loss versus fertilizer $\mathrm{N}$ and of the slope of relative evapotranspiration (ET) versus fertilizer $\mathrm{N}$ for two growing seasons; lower and upper limits of the basic bootstrapping $95 \%$ confidence interval for each slope estimate without interactions are in parentheses

\begin{tabular}{|c|c|c|c|c|}
\hline \multirow[t]{2}{*}{ Water level } & \multicolumn{2}{|c|}{$\begin{array}{l}\text { Slope }\left(\mathrm{m}^{3} \mathrm{~m}^{-3} \mathrm{~kg}^{-1} \text { ha) of soil water loss }\right. \\
\left(\mathrm{m}^{3} \mathrm{~m}^{-3}\right) \text { vs. fertilizer } \mathrm{N}\left(\mathrm{kg} \mathrm{ha}^{-1}\right)\end{array}$} & \multicolumn{2}{|c|}{$\begin{array}{l}\text { Slope }\left(\mathrm{kg}^{-1} \text { ha) of relative ET (unit }\right. \\
\text { less) vs. fertilizer } \mathrm{N}\left(\mathrm{kg} \mathrm{ha}^{-1}\right)\end{array}$} \\
\hline & 2017 & 2018 & 2017 & 2018 \\
\hline \multicolumn{5}{|c|}{ Assuming no water level $\times \mathrm{N}$ level interactions } \\
\hline All & $\begin{array}{l}1.5 \mathrm{E}-4 \\
(0.8 \mathrm{E}-4, \\
2.1 \mathrm{E}-4)\end{array}$ & $\begin{array}{l}2.3 \mathrm{E}-4 \\
(1.7 \mathrm{E}-4, \\
2.9 \mathrm{E}-4)\end{array}$ & $\begin{array}{l}0.4 \mathrm{E}-4 \\
(-2.7 \mathrm{E}-4 \\
3.6 \mathrm{E}-4)\end{array}$ & $\begin{array}{l}8.8 \mathrm{E}-4 \\
(2.7 \mathrm{E}-4, \\
14.9 \mathrm{E}-4)\end{array}$ \\
\hline \multicolumn{5}{|c|}{ Assuming water level $\times \mathrm{N}$ level interactions } \\
\hline No irrigation & $1.1 \mathrm{E}-4$ & $1.6 \mathrm{E}-4$ & $-1.3 \mathrm{E}-4$ & $8.1 \mathrm{E}-4$ \\
\hline Alternate irrigation & $1.9 \mathrm{E}-4$ & $3.1 \mathrm{E}-4$ & $0.3 \mathrm{E}-4$ & $10.7 \mathrm{E}-4$ \\
\hline Full irrigation & $1.4 \mathrm{E}-4$ & $2.1 \mathrm{E}-4$ & $2.2 \mathrm{E}-4$ & $7.7 \mathrm{E}-4$ \\
\hline
\end{tabular}

Furthermore, the corn plants of Carroll et al. (2017) grew in 11.4-L pots during the greenhouse component and in $0.45 \mathrm{~m}$ of artificial topsoil overlying a compacted natural subsoil during the field component. Both environments most likely prevented the additional expansion of rooting volume with increasing $\mathrm{N}$ levels. Therefore, for users of above canopy IRTs, aerial thermal cameras, and satellite longwave radiometers, Carroll et al. (2017) provide little relevant evidence that $\mathrm{N}$ stress will never confound measurements of canopy temperature and Crop Water Stress Index. Caution is still warranted when interpreting thermal data when variable water sufficiency and variable $\mathrm{N}$ sufficiency are simultaneously significant.

In some rare situations (the no irrigation level in both Fig. 3a, p), $T_{\mathrm{c}}$ actually increased with increasing $\mathrm{N}$ levels. These particular situations were predominantly under no irrigation at times of very large soil water depletion (Fig. 1). Interestingly, Nielsen and Halvorson (1991) also reported that increasing $\mathrm{N}$ levels decreased $T_{\mathrm{c}}$ under mild water stress but increased $T_{\mathrm{c}}$ under severe water stress. One plausible explanation could be that plots receiving higher $\mathrm{N}$ levels had higher ET earlier in the growing season and were now suffering more severe water stress because of greater soil water depletion. Senescence could even be accelerated. If this explanation is indeed correct, the $\mathrm{N}$ impact on $T_{\mathrm{c}}$ should be understood as the net product of multiple competing physical processes rather than a simplistic decrease in $T_{\mathrm{c}}$ with increasing $\mathrm{N}$ levels. Regardless, this study highlighted the complexity and temporal variability of the relationship between water availability, $\mathrm{N}$ levels and $T_{\mathrm{c}}$, which ought to be considered carefully.

\section{Linear mixed models}

According to type III $F$ tests, the seasonal results were mildly incompatible ( $p=0.08$ in 2017 and 0.04 in 2018) with equal slopes of soil water loss versus fertilizer $\mathrm{N}$ among the three water levels. Just as visually suggested by Fig. $2 \mathrm{f}$, slope estimates for both years were almost twice as high for alternate irrigation than for no irrigation (Table 3). However, the seasonal results were strongly incompatible $(p=0.004$ in 2017 and 0.00005 in 2018) with a zero slope of soil water loss versus fertilizer $\mathrm{N}$ when pooling together all water levels. Slope estimates of 0.00015 and $0.00023 \mathrm{~m}^{3} \mathrm{~m}^{-3} \mathrm{~kg}^{-1}$ ha (Table 3) corresponded to about 0.04 and $0.06 \mathrm{~m}^{3} \mathrm{~m}^{-3}$ difference in seasonal soil water loss within the top $1.5 \mathrm{~m}$ over the fertilizer $\mathrm{N}$ range of this study, which are practically important magnitudes for crop production.

According to type III $F$ tests again, the seasonal results constituted negligible evidence $(p=0.20$ in 2017 and 0.36 in 2018) against equal slopes of relative ET versus fertilizer $\mathrm{N}$ among the three water levels. The slope appeared to be distinctly different among water levels on particular dates (Fig. 3a, p), but such differences became small relative to interreplicate variability after averaging across all eight measurement dates of the same year. Yet against a zero slope of soil water loss versus fertilizer $\mathrm{N}$ when pooling together all water levels, the seasonal results provided moderate evidence $(p=0.02)$ in 2018 but not in 2017 ( $p=0.82$ ). This finding is in agreement with the observation that canopy temperatures were usually higher for $0 \mathrm{~kg} \mathrm{ha}^{-1}$ fertilizer $\mathrm{N}$ than for higher $\mathrm{N}$ levels in 2018 (Fig. 3i-o) but canopy temperature trends with respect to $\mathrm{N}$ level were largely masked by interreplicate variability in 2017 (Fig. 3b-h). A slope of $0.00088 \mathrm{~kg}^{-1}$ ha (Table 3 ) corresponded to about 0.24 difference in relative ET over the fertilizer $\mathrm{N}$ range of this study, which is a practically important magnitude for crop production. The $95 \%$ confidence interval for this slope estimate was wide though. Its lower and upper limits were about $30 \%$ and $170 \%$ of the estimate, respectively (Table 3 ).

\section{Implications for sensor-based management of water and nitrogen}

\section{Vegetation indices}

Vegetation indices (VIs) have been used to estimate ET crop coefficients (Bausch and Neale 1987; DeJonge et al. 


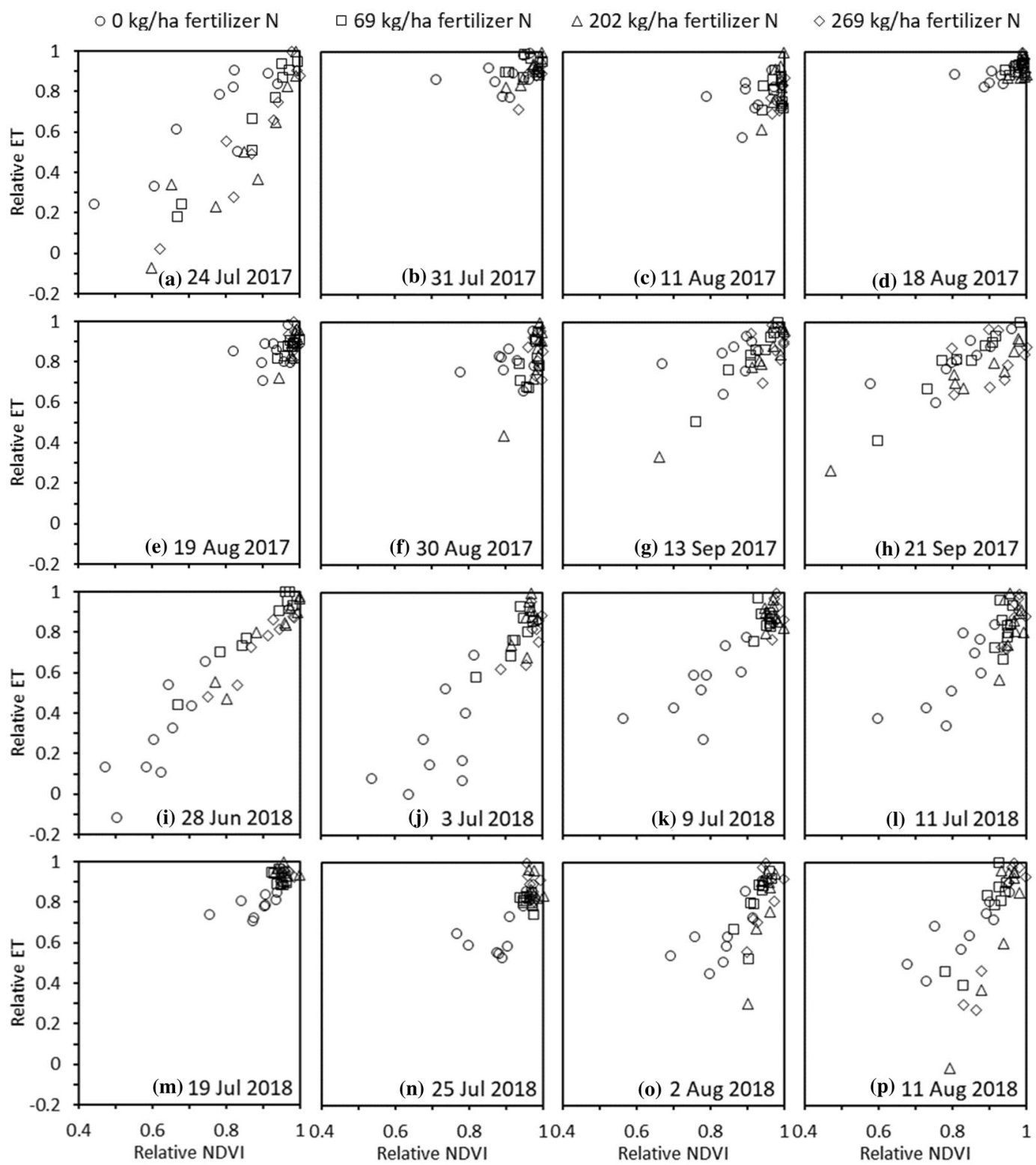

Fig. 4 Scatterplots of relative evapotranspiration (ET) versus relative normalized difference vegetation index (NDVI) at 16 measurement times

2016; Barker et al. 2018) by accounting for canopy changes throughout a growing season. This study explored the use of VIs to account for ET differences under various water $\times \mathrm{N}$ treatments by examining the relationship between relative VI and relative ET. Other VIs besides NDVI were investigated but were not included in this paper. The ratio vegetation index and the optimized soil adjusted vegetation index did not reduce saturation that NDVI encountered in this dataset. On the other hand, the red edge normalized difference vegetation index and the Datt (1999) VI both reduced saturation but tended to exhibit weaker linear correlations with ET.

Across all measurement times, relative NDVI and relative ET were generally positively correlated (Fig. 4). Pooling together all replicates of all treatment combinations, the correlation coefficient values ranged from 0.33 to 0.96 among the 16 measurement times, with a median of 0.74 . This result suggests that NDVI captured much of the inter-plot differences in canopy growth, pigmentation, rolling, wilting, and/or senescence that arose from implementing water $\times \mathrm{N}$ treatments and that contributed heavily to the inter-plot differences in ET (DeJonge et al. 2016). Just like $T_{\mathrm{c}}$ was most variable among non-irrigated plots during times of severe water stress (Fig. 3), the relationship between relative NDVI and relative ET was most variable among non-fertilized plots during times of severe $\mathrm{N}$ stress (Fig. 4). 
Fig. 5 Scatterplots of relative evapotranspiration (ET) versus soil water depletion within the top $1.5 \mathrm{~m}$ in a late July 2017 and b early August 2018; see text for exact dates

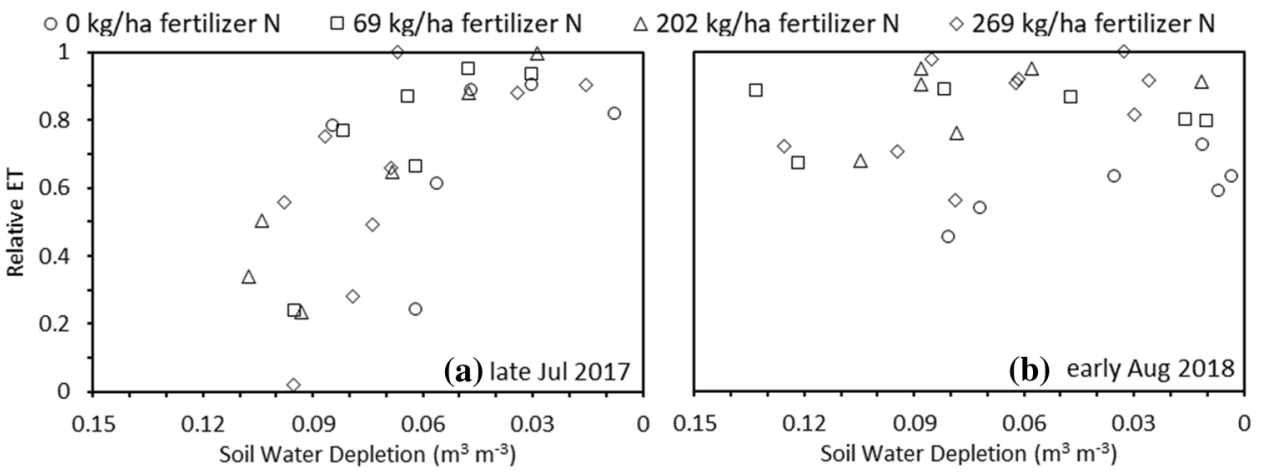

At some measurement times, all $\mathrm{N}$ levels followed the same relative ET versus relative NDVI relationship. Yet at other measurement times, one or more $\mathrm{N}$ levels followed different relationships. The diversity in relative NDVI versus relative ET relationships at a particular measurement time appeared to be attributed to past and present stresses. At the mid vegetative measurement times of 2018 (Fig. $4 \mathrm{i}-\mathrm{j}$ ), water stress was absent while $\mathrm{N}$ stress was severe. The $\mathrm{N}$-induced differences in canopy were directly quantified by NDVI, whereas the N-induced differences in leaf internal characteristics and rooting volume (see previous subsection) were indirectly correlated with NDVI. Because these three types of $\mathrm{N}$-induced differences were the main drivers of ET differences at these measurement times, only one relative NDVI versus relative ET relationship existed. On 24 July 2017 (Fig. 4a) and at the measurement times in September 2017 (Fig. 4g-h) and August 2018 (Fig. 4o-p), however, water stress and $\mathrm{N}$ stress were simultaneously occurring. The concurrence of both stresses complicates the application of NDVI for at least two reasons. First, an aboveground, macroscopic optical measurement such as NDVI cannot directly detect differences in stomatal conductance and rooting volume, both of which are expected to be significant drivers of ET differences when soil water depletion is large. Second, NDVI responds to $\mathrm{N}$ induced canopy differences and to water induced canopy differences (Shiratsuchi et al. 2011; Ward, 2015; Lo et al. 2019). The same relative NDVI could be obtained from plots with markedly different combinations of water stress and $\mathrm{N}$ stress, which in turn could correspond to markedly different relative ET. These two reasons explain at least in part the existence of multiple relationships between relative NDVI and relative ET among $\mathrm{N}$ levels at these measurement times. As for measurement times such as 18 August 2017 (Fig. 4d) when most plots had recovered from earlier water stress and $\mathrm{N}$ stress, all data points merely formed one cluster with similar NDVI and ET values.

Overall, NDVI was found to be a powerful predictor of ET differences among water $\times \mathrm{N}$ treatments, but it is not always sufficient on its own and should be interpreted with caution. NDVI differences can represent water differences, $\mathrm{N}$ differences, both, or neither. What NDVI represents specifically and how it relates to other variables depend critically on what the crop underwent to attain its current NDVI value. Measuring NDVI just once is not expected to be a reliable method of fully accounting for ET differences when water stress and $\mathrm{N}$ stress are potentially concurrent.

\section{Soil water depletion}

The discussion in the previous subsection hinted at the potential of using soil water depletion to account for portions of ET differences for which NDVI does not account under various water $\times \mathrm{N}$ treatments. Furthermore, if $\mathrm{N}$ stress could alter the relationship between soil water depletion and relative ET, growers may wonder whether irrigation should be triggered at a different soil water depletion threshold in the presence of $\mathrm{N}$ stress. These questions were investigated by examining the relationship between soil water depletion and relative ET. The analysis focused on two times when water stress and $\mathrm{N}$ stress were simultaneously occurring and when no irrigation was applied between the set of NMM measurements and the set of IRT measurements.

Figure 5a used NMM measurements on 22 July 2017 and $T_{\mathrm{c}}$ measurements on 24 July 2017 . There was no rain between these two sets of measurements, so Fig. 5a underestimated slightly the soil water depletion value that was associated with each relative ET value. The crop was less than one week before R1, and N stress had begun not too long ago. At all $\mathrm{N}$ levels, relative ET appeared to stay near 0.9 until soil water depletion exceeded $0.05 \mathrm{~m}^{3} \mathrm{~m}^{-3}$. At the lowest $\mathrm{N}$ level, two out of the three plots with soil water depletion above $0.05 \mathrm{~m}^{3} \mathrm{~m}^{-3}$ might suggest a steeper decrease in relative ET per unit of soil water depletion, but the other plot followed the trajectory of higher $\mathrm{N}$ levels. Overall, the evidence for $\mathrm{N}$ dependence in the soil water depletion thresholds and slopes for ET reduction was weak in late July 2017.

Figure 5b used NMM measurements and $T_{\mathrm{c}}$ measurements both on 2 August 2018. The crop was at R3, and 
$\mathrm{N}$ stress had been occurring for much longer. At the three higher $\mathrm{N}$ levels, relative ET of the plots stayed around 0.9 until soil water depletion surpassed $0.09 \mathrm{~m}^{3} \mathrm{~m}^{-3}$. This higher threshold (relative to $0.05 \mathrm{~m}^{3} \mathrm{~m}^{-3}$ in Fig. 5a) may be attributed perhaps to (1) a shorter delay in the occurrence of $T_{\mathrm{c}}$ measurements after the occurrence of NMM measurements, (2) a less water sensitive growth stage, and (3) a lower evaporative demand (Table 2). In contrast, no plot at the lowest $\mathrm{N}$ level approached relative ET of 1 regardless of soil water depletion presumably because of the aforementioned $\mathrm{N}$-induced differences in canopy, in leaf characteristics, and in rooting volume. The relative ET of these $0 \mathrm{~kg} \mathrm{ha}^{-1}$ fertilizer $\mathrm{N}$ plots clustered around 0.65 with soil water depletion under $0.04 \mathrm{~m}^{3} \mathrm{~m}^{-3}$ and decreased to about 0.5 with soil water depletion around $0.075 \mathrm{~m}^{3} \mathrm{~m}^{-3}$. Although the exact threshold and slope for ET reduction could not be estimated for the lowest $\mathrm{N}$ level because plots with intermediate soil water depletion were lacking, the evidence for $\mathrm{N}$ dependence in these parameters was strong in early August 2018.

Soil water depletion can indeed account partially for relative ET differences under water $\times \mathrm{N}$ treatments - though to a much greater extent in some circumstances (Fig. 5a) than in others (Fig. 5b). Yet with the differences between Fig. 5a, b and with the differences between $0 \mathrm{~kg} \mathrm{ha}^{-1}$ fertilizer $\mathrm{N}$ and the higher $\mathrm{N}$ levels in Fig. 5b, the relationship between soil water depletion and relative ET is inferred to be not only variable in time but also potentially variable with $\mathrm{N}$ levels. Long durations of $\mathrm{N}$ stress (e.g., Fig. 5b), in particular, might increase the likelihood of altering the soil water depletion threshold and/or slope for ET reduction. Whenever the relative ET versus soil water depletion relationship varies with $\mathrm{N}$ status, soil water depletion cannot be used to assess water stress independent of $\mathrm{N}$ stress. Data limitations in this study regrettably prevented the confident development of recommendations for irrigation management under concurrent water stress and $\mathrm{N}$ stress. If further research is conducted with this goal in mind, designing a greater number of spatial replicates and a greater frequency of near simultaneous soil water and ET measurements would be essential.

\section{Combined stress factor}

Having found that NDVI and soil water depletion each account partially for relative ET differences under water $\times \mathrm{N}$ treatments, this study tested whether the combined use of both NDVI and soil water depletion could account for more of the relative ET differences than either variable could alone. A complex model could be built in the future, but a simple multiplicative approach (Wright, 1982; Allen et al. 1998) was adopted in this study for a proof of concept. In this approach, a combined stress factor was calculated as the product of two component factors-a canopy factor and a soil water factor (Eq. 2).
Relative NDVI was chosen as the canopy factor in the following analysis. The remaining fraction of available water was chosen as the soil water factor in the following analysis and was estimated as 1 -(soil water depletion) $) /(0.17$ $\mathrm{m}^{3} \mathrm{~m}^{-3}$ ), where the denominator is a local approximation of available water capacity (Klocke et al. 1999). The canopy factor is conceptually similar to the "basal crop coefficient" $K_{\mathrm{cb}}$ in Wright (1982) and Allen et al. (1998). The soil water factor is conceptually similar to the "available soil moisture coefficient" $K_{\mathrm{a}}$ in Wright (1982) and the "water stress coefficient" $K_{\mathrm{s}}$ in Allen et al. (1998). However, the new terminology was introduced in this study to allow for differences in definitions from those by Wright (1982) and Allen et al. (1998). For ease of comparison, the analysis focused on the same two times featured in Fig. 5.

$K_{\mathrm{m}, \mathrm{u}}=K_{\text {cnp }} \times K_{\mathrm{sw}}$,

where $K_{\mathrm{m}, \mathrm{u}}=$ unweighted combined stress factor (unitless), $K_{\text {cnp }}=$ canopy factor (unitless), and $K_{\mathrm{sw}}=$ soil water factor (unitless).

The simple approach worked well for late July 2017. Figure 6a placed all $\mathrm{N}$ levels on the same trend, which contrasted sharply with Figs. 4a and 5a. Synthesizing those two earlier figures, lower $\mathrm{N}$ levels tended to experience higher relative ET at this particular time than expected based on relative NDVI because more available water was remaining in these plots. This phenomenon could not be described fully using NDVI or soil water depletion in isolation. Coincidentally, the range in relative NDVI and the range in the remaining fraction of available water were similar at this time, so the canopy factor and the soil water factor each had similar influence over the unweighted combined stress factor (Eq. 2).

For early August 2018, on the other hand, Fig. 6b displayed no discernable improvement over Figs. $4 \mathrm{o}$ and $5 \mathrm{~b}$. The unweighted combined stress factor (Fig. 6b) did not exhibit a stronger association with relative ET than did soil water depletion (Fig. 5b), and the lowest $\mathrm{N}$ level stayed on a clearly separate trend. Although relative NDVI (Fig. 4o) accounted for much more of the relative ET differences than did soil water depletion (Fig. 5b), the range in relative NDVI was considerably smaller than the range in the remaining fraction of available water. Owing to this disparity in range, the influence of relative NDVI and of the remaining fraction of available water on the unweighted combined stress factor (Eq. 2) were, respectively, deflated and inflated by the simple approach as described above, which was contrary to reality.

A more robust system would be necessary in practice to minimize the occurrence of such undesirable results. In the meanwhile, a rudimentary weighting scheme was attempted below for illustrative purposes assuming that the relative weight of the canopy factor versus the soil 


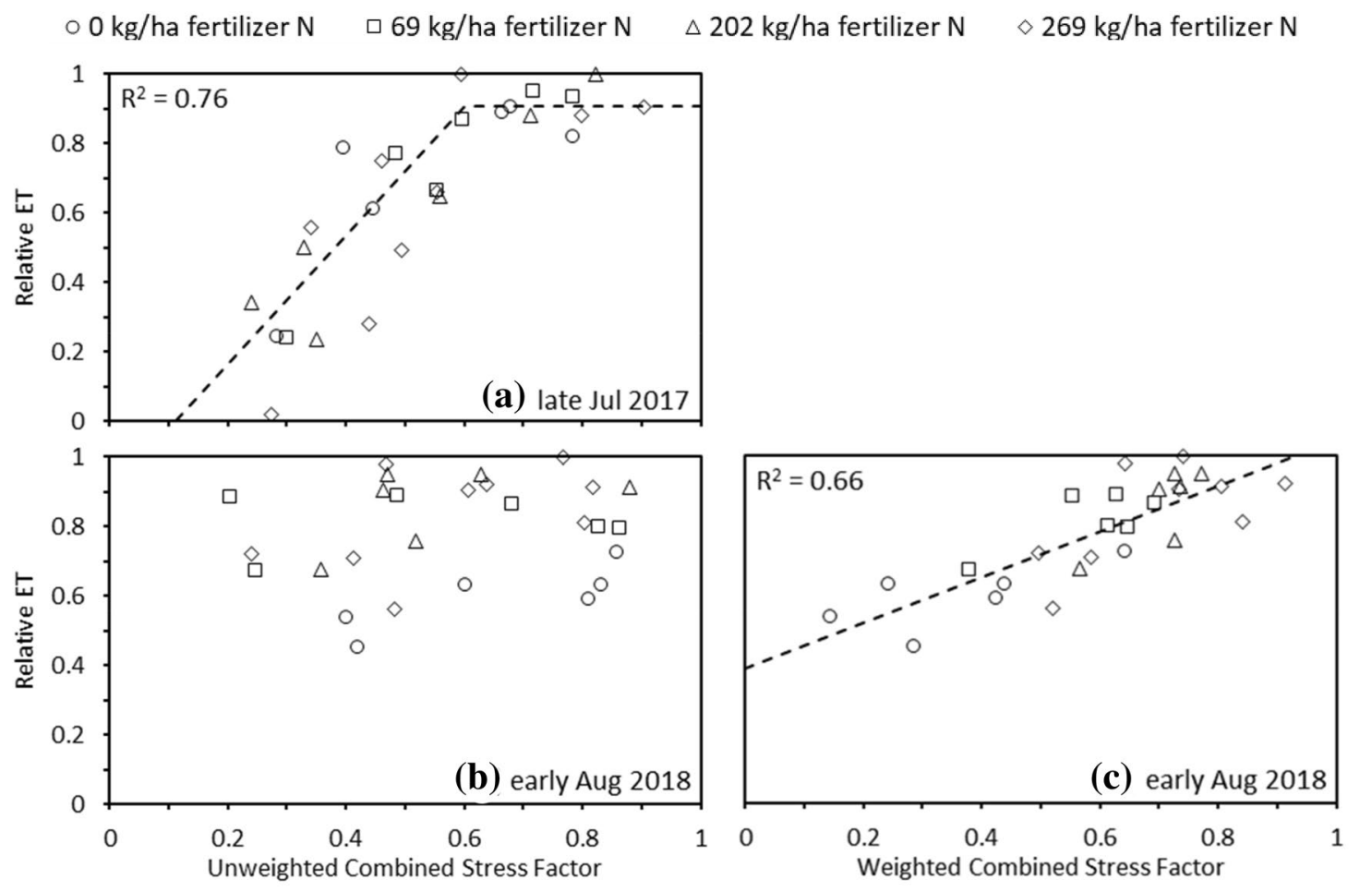

Fig. 6 Scatterplots of relative evapotranspiration (ET) versus the combined stress factor in a late July 2017 (unweighted), b early August 2018 (unweighted), c early August 2018 (weighted); see text for details

water factor could be known beforehand. One exponent was assigned to the canopy factor, and another exponent was assigned to the soil water factor (Eq. 3). An exponent value greater than 1 expanded the range of and increased the weight of the corresponding factor, whereas an exponent value less than 1 shrunk the range of and decreased the weight of the corresponding factor. No pair of exponents produced noticeable improvement for late July 2017 (not shown), yet an exponent of 5 for relative NDVI and an exponent of 0.2 for the remaining fraction of available water appeared to place all $\mathrm{N}$ levels on the same trend (Fig. 6c).

$K_{\mathrm{m}, \mathrm{w}}=K_{\mathrm{cnp}}^{a} \times K_{\mathrm{sw}}^{b}$,

where $K_{\mathrm{m}, \mathrm{w}}=$ weighted combined stress factor (unitless), $a=$ weighting exponent for canopy factor (unitless), and $b=$ weighting exponent for soil water factor (unitless).

Despite the obvious need for refinement, combining NDVI and soil water depletion to account for relative ET differences under variable water sufficiency and variable $\mathrm{N}$ sufficiency has been demonstrated by this study to be a promising concept. Future studies could evaluate the suitability of (1) various canopy and soil water sensors for this approach, (2) various definitions of the canopy factor and the soil water factor, and (3) various formulations of the combined stress factor. To keep track of the relative importance of each component factor to ensure appropriate weighting, the complete approach may need to be implemented in a stepwise manner throughout the growing season. Developing a widely applicable approach will be undoubtedly challenging because it must handle the diverse interactions between canopy and soil water and between water and $\mathrm{N}$.

To clarify, the canopy factor is not a pure $\mathrm{N}$ stress factor and that the soil water factor is not a pure water stress factor. The interpretation of canopy measurements and the interpretation of soil water measurements are each conditional on both water and $\mathrm{N}$. The three state of the art methods for measuring N stress-tissue sampling (González-Dugo et al. 2010), chlorophyll meters (Schepers et al. 1996; Schlemmer et al. 2005; Songsri et al. 2009), and active optical sensors (Shiratsuchi et al. 2011; Ward, 2015; Lo et al. 2019)—are all affected by water stress. Similarly, the relationship between water stress and measures of soil or leaf water status is affected by $\mathrm{N}$ stress. At least with the modern repertoire of sensors, a clean and elegant separation of these two stresses remains difficult. To characterize and distinguish the two stresses when both are potentially present, the crop should be traced using a time series of plant, soil, and/or weather measurements. Successful sensor-based management must imitate skilled scouts and agronomists by considering all 
relevant information to generate proper diagnoses and recommendations.

\section{Conclusion}

This study affirmed previous studies that $\mathrm{N}$ can influence crop water relations. Soil water loss within the top $1.5 \mathrm{~m}$ tended to increase with $\mathrm{N}$ level in both 2017 and 2018. Relative instantaneous ET tended to increase with $\mathrm{N}$ level in 2018 but displayed no consistent and notable trend relative to $\mathrm{N}$ level in 2017. Yet more so than some previous studies, the influence of $\mathrm{N}$ was found to be complex and highly dynamic instead of monotonic and static (Fig. 3). Whether and how much ET varied with $\mathrm{N}$ levels depended on circumstances that differed between and within growing season (Fig. 4). To account for this phenomenon, this study proposed an approach (Eqs. 2-3) of combining canopy reflectance and soil water depletion to model ET differences due to variable water sufficiency and variable $\mathrm{N}$ sufficiency. Moderate success was observed for this novel approach (Fig. 6). Interested colleagues are strongly encouraged to improve, assess, and apply the approach.

The approach can be incorporated into various end uses including crop modeling and irrigation scheduling. Values of the canopy factor and the soil water factor that are obtained from sensors can be then assimilated into models to enhance the accuracy of ET simulations and the appropriateness of irrigation decisions. For soil water sensors, the approach can inform the choice of irrigation triggering thresholds and also provide a canopy specific, water sufficient ET rate that can be compared against the drying rate of sensor readings. For infrared thermometry, the approach can provide canopy specific baselines for the Crop Water Stress Index. It is uncertain whether the non-evapotranspiring and the freely evapotranspiring surface temperatures for a low NDVI value would be the same if this low NDVI value is attributed to partial cover (Moran et al. 1994) or to N stress. It is likewise uncertain whether the relationship between NDVI and surface temperature baselines varies with growth stages. Before the approach can be useful in practice, these questions and many more need to be addressed.

Applying this approach will require plenty of data, which may become increasingly available in the future of digital agriculture. Closely monitoring crop canopies and soil water at the field or sub-field scales will be greatly facilitated by emerging technologies including (1) distributed sensor networks with telemetry; (2) individual or swarms of unmanned ground/aerial vehicles; (3) routine, high resolution airplane and satellite imagery; and (4) advanced algorithms for data processing, stress identification, and management recommendations. Only time will tell whether and how these tools will be used to assist integrated thinking about and conjunctive management of water and $\mathrm{N}$ for the benefit of farm profitability and environmental stewardship.

Acknowledgements The authors are grateful to Turner Dorr, Jacob Nickel, Odile Umuhoza, Raïssa Urujeni, Von Fritsche, Jasreman Singh, and Roberto Arellano-Choca for their involvement with data collection; to Gary Mahnken and Merle Still for their supporting roles in field management; to Holland Scientific, Lindsay Corporation, Holzfasters Irrigation, and SureFire Ag Systems for their timely technical support; to Nebraska State Climate Office for their Nebraska Mesonet weather data; and to Debbie Boykin for her statistical consulting. This study is based upon work that was jointly supported by the United States Department of Agriculture's National Institute of Food and Agriculture under award numbers 2016-68007-25066 and 2017-68007-26584 and under Hatch projects \#1009760 and \#1015698; the United States Department of Agriculture's Agricultural Research Service under cooperative agreement number 58-6001-7-001; the Nebraska Corn Board under award number 88-R-1617-06; the Daugherty Water for Food Global Institute; and the University of Nebraska-Lincoln Institute of Agriculture and Natural Resources.

\section{Compliance with ethical standards}

Conflict of interest On behalf of all authors, the corresponding author states that there is no conflict of interest.

\section{References}

Abendroth LJ, Elmore RW, Boyer MJ, Marlay SK (2011) Corn growth and development. Iowa State University, Ames

Albrizio R, Todorovic M, Matic T, Stellacci AM (2010) Comparing the interactive effects of water and nitrogen on durum wheat and barley grown in a mediterranean environment. Field Crops Res 115(2):179-190. https://doi.org/10.1016/j.fcr.2009.11.003

Allen RG, Wright JL (1997) Translating wind speed measurements from weather stations to agricultural crops. J Hydrol Eng 2(1):2635. https://doi.org/10.1061/(ASCE)1084-0699(1997)2:1(26)

Barker JB, Heeren DM, Neale CMU, Rudnick DR (2018) Evaluation of variable rate irrigation using a remote-sensing-based model. Agric Water Manag 203:63-74. https://doi.org/10.1016/j.agwat .2018.02.022

Bates D, Maechler M, Bolker B, Walker S (2015) Fitting linear mixedeffects models using lme4. J Stat Softw 67(1):1-48. https://doi. org/10.18637/jss.v067.i01

Bausch WC, Neale CMU (1987) Crop coefficients derived from reflected canopy radiation: a concept. Trans ASAE 30(3):703709. https://doi.org/10.13031/2013.30463

Carroll DA II, Hansen NC, Hopkins BG, DeJonge KC (2017) Leaf temperature of maize and crop water stress index with variable irrigation and nitrogen supply. Irrig Sci 35(6):549-560. https:// doi.org/10.1007/s00271-017-0558-4

Clawson KL, Blad BL (1982) Infrared thermometry for scheduling irrigation of corn. Agron J 74(2):311-316. https://doi.org/10.2134/ agronj1982.00021962007400020013x

Datt B (1999) Visible/near infrared reflectance and chlorophyll content in eucalyptus leaves. Int J Remote Sens 20(14):2741-2759. https ://doi.org/10.1080/014311699211778

DeJonge KC, Mefford BS, Chávez JL (2016) Assessing corn water stress using spectral reflectance. Int J Remote Sens 37(10):2294 2312. https://doi.org/10.1080/01431161.2016.1171929 
Fois S, Motzo R, Giunta F (2009) The effect of nitrogenous fertiliser application on leaf traits in durum wheat in relation to grain yield and development. Field Crops Res 110(1):69-75. https://doi. org/10.1016/j.fcr.2008.07.004

Gheysari M, Mirlatifi SM, Bannayan M, Homaee M, Hoogenboom $\mathrm{G}$ (2009) Interaction of water and nitrogen on maize grown for silage. Agric Water Manag 96(5):809-821. https://doi. org/10.1016/j.agwat.2008.11.003

González-Dugo MP, Moran MS, Mateos L, Bryant R (2006) Canopy temperature variability as an indicator of crop water stress severity. Irrig Sci 24:233-240. https://doi.org/10.1007/s0027 $1-005-0022-8$

González-Dugo V, Durand J-L, Gastal F (2010) Water Deficit and nitrogen nutrition of crops: a review. Agron Sustain Dev 30(3):529544. https://doi.org/10.1051/agro/2009059

Halekoh U, Højsgaard S (2014) A Kenward-Roger approximation and parametric bootstrap methods for tests in linear mixed models: the $\mathrm{R}$ package pbkrtest. J Stat Softw 59(9):1-32. https://doi.org/10.18637 /jss.v059.i09

Han M, Zhang H, DeJonge KC, Comas LH, Trout TJ (2016) Estimating maize water stress by standard deviation of canopy temperature in thermal imagery. Agric Water Manag 177:400-409. https://doi. org/10.1016/j.agwat.2016.08.031

Jackson RD, Kustas WP, Choudhury BJ (1988) A Reexamination of the crop water stress index. Irrig Sci 9(4):309-317. https://doi. org/10.1007/BF00296705

Klocke NL, Watts DG, Schneekloth JP, Davison DR, Todd RW, Parkhurst AM (1999) Nitrate leaching in irrigated corn and soybean in a semi-arid climate. Trans ASAE 42(6):1621-1630. https://doi. org/10.13031/2013.13328

Kranz WL, Irmak S, van Donk SJ, Yonts CD, Martin DL (2008) Irrigation management for corn. NebGuide G1850. University of Nebraska-Lincoln Extension, Lincoln. Retrieved from https://exten sionpublications.unl.edu/assets/pdf/g1850.pdf

Kustas WP, Anderson MC, Norman JM, Li F (2007) Utility of radiometric-aerodynamic temperature relations for heat flux estimation. Bound Layer Meteorol 122(1):167-187. https://doi.org/10.1007/ s10546-006-9093-1

Kuznetsova A, Brockhoff PB, Christensen RHB (2017) lmerTest package: tests in linear mixed effects models. J Stat Softw 82(13):1-26. https ://doi.org/10.18637/jss.v082.i13

Lenka S, Singh AK, Lenka NK (2009) Water and nitrogen interaction on soil profile water extraction and et in maize-wheat cropping system. Agric Water Manag 96(2):195-207. https://doi.org/10.1016/j.agwat .2008.06.014

Lo T, Rudnick DR, Krienke BT, Heeren DM, Ge Y, Shaver TM (2019) Water effects on optical canopy sensing for late-season site-specific nitrogen management of maize. Comput Electron Agric 162:154164. https://doi.org/10.1016/j.compag.2019.04.006

Mansouri-Far C, Modarres Sanavy SAM, Saberali SF (2010) Maize yield response to deficit irrigation during low-sensitive growth stages and nitrogen rate under semi-arid climatic conditions. Agric Water Manag 97(1):12-22. https://doi.org/10.1016/j.agwat.2009.08.003

Mon J, Bronson KF, Hunsaker DJ, Thorp KR, White JW, French AN (2016) Interactive effects of nitrogen fertilization and irrigation on grain yield, canopy temperature, and nitrogen use efficiency in overhead sprinkler-irrigated durum wheat. Field Crops Res 191:54-65. https://doi.org/10.1016/j.fcr.2016.02.011

Moran MS, Clarke TR, Inoue Y, Vidal A (1994) Estimating crop water deficit using the relation between surface-air temperature and spectral vegetation index. Remote Sens Environ 49(3):246-263. https:// doi.org/10.1016/0034-4257(94)90020-5

Nielsen DC, Halvorson AD (1991) Nitrogen fertility influence on water stress and yield of winter wheat. Agron J 83(6):1065-1070. https:// doi.org/10.2134/agronj1991.00021962008300060025x
Ogola JBO, Wheeler TR, Harris PM (2002) Effects of nitrogen and irrigation on water use of maize crops. Field Crops Res 78(2-3):105-117. https://doi.org/10.1016/S0378-4290(02)00116-8

Pandey RK, Maranville JW, Chetima MM (2000) Deficit irrigation and nitrogen effects on maize in a Sahelian environment: II. shoot growth, nitrogen uptake and water extraction. Agric Water Manag 46(1):15-27. https://doi.org/10.1016/S0378-3774(00)00074-3

Peñuelas J, Filella I, Serrano L, Savé R (1996) Cell wall elasticity and water index $(\mathrm{R} 970 \mathrm{~nm} / \mathrm{R} 900 \mathrm{~nm})$ in wheat under different nitrogen availabilities. Int J Remote Sens 17:373-382. https://doi. org/10.1080/01431169608949012

R Core Team (2020) R: a language and environment for statistical computing. R Foundation for Statistical Computing, Vienna

Rudnick DR, Irmak S (2014a) Spatial and temporal maize soil water extraction (depletion) dynamics: part II. Impact of water and nitrogen management strategies on soil water extraction. Trans ASABE 57(2):445-462. https://doi.org/10.13031/trans.57.10254

Rudnick DR, Irmak S (2014b) Impact of nitrogen fertilizer on maize evapotranspiration crop coefficients under fully irrigated, limited irrigation, and rainfed settings. J Irrig Drain Eng 140(12):04014039. https://doi.org/10.1061/(ASCE)IR.1943-4774.0000778

Rudnick DR, Irmak S, Djaman K, Sharma V (2017) Impact of irrigation and nitrogen fertilizer rate on soil water trends and maize evapotranspiration during the vegetative and reproductive periods. Agric Water Manag 191:77-84. https://doi.org/10.1016/j.agwat .2017 .06 .007

Saneoka H, Moghaieb REA, Premachandra GS, Fujita K (2004) Nitrogen nutrition and water stress effects on cell membrane stability and leaf water relations in Agrostis palustris huds. Environ Exp Bot 52(2):131-138. https://doi.org/10.1016/j.envexpbot.2004.01.011

Schlemmer MR, Francis DD, Shanahan JF, Schepers JS (2005) Remotely measuring chlorophyll content in corn leaves with differing nitrogen levels and relative water content. Agron J 97(1):106-112. https://doi. org/10.2134/agronj2005.0106

Seligman NG, Loomis RS, Burke J, Abshahi A (1983) Nitrogen nutrition and canopy temperature in field-grown spring wheat. J Agric Sci 101(3):691-697. https://doi.org/10.1017/S0021859600038727

Shangguan ZP, Shao MA, Dyckmans J (2000) Nitrogen nutrition and water stress effects on leaf photosynthetic gas exchange and water use efficiency in winter wheat. Environ Exp Bot 44(2):141-149. https://doi.org/10.1016/S0098-8472(00)00064-2

Shaver TM, Kruger GR, Rudnick DR (2017) Crop canopy sensor orientation for late season nitrogen determination in corn. J Plant Nutr 40(15):2217-2223. https://doi.org/10.1080/01904167.2017.1346681

Shiratsuchi LS, Ferguson RB, Shanahan JF, Adamchuk VI, Rundquist DC, Marx DB, Slater GP (2011) Water and nitrogen effects on active canopy sensor vegetation indices. Agron J 103(6):1815-1826. https ://doi.org/10.2134/agronj2011.0199

Spalding RF, Watts DG, Schepers JS, Burbach ME, Exner ME, Poreda RJ, Martin GE (2001) Controlling nitrate leaching in irrigated agriculture. J Environ Qual 30(4):1184-1194. https://doi.org/10.2134/ jeq2001.3041184x

Task Committee on Standardization of Reference Evapotranspiration (2005) In: Allen RG, Walter IA, Elliott RL, Howell TA, Itenfisu D, Jensen ME (eds) The ASCE standardized reference evapotranspiration equation. Environmental and Water Resources Institute of the American Society of Civil Engineers, Reston

Tilling AK, O'Leary GJ, Ferwerda JG, Jones SD, Fitzgerald GJ, Rodriguez D, Belford $\mathrm{R}$ (2007) Remote sensing of nitrogen and water stress in wheat. Field Crops Res 104(1-3):77-85. https://doi. org/10.1016/j.fcr.2007.03.023

van Herwaarden AF, Farquhar GD, Angus JF, Richards RA, Howe GN (1998) "Haying-Off", the negative grain yield response of dryland wheat to nitrogen fertiliser: I. Biomass, grain yield, and water use. Aust J Agric Res 49(7):1067-1082. https://doi.org/10.1071/A97039 
Ward NC (2015) Nitrogen and water effects on canopy sensor measurements for site-specific management of crops (Doctoral dissertation). University of Nebraska-Lincoln, Lincoln, NE. Retrieved from https ://digitalcommons.unl.edu/cgi/viewcontent.cgi?article=1094\&conte $\mathrm{xt}=$ agronhortdiss

Wright JL (1982) New evapotranspiration crop coefficients. J Irrig Drain Div 108(1):57-74

Yang DQ, Dong WH, Luo YL, Song WT, Cai T, Li Y, Yin YP, Wang ZL (2018) Effects of nitrogen application and supplementary irrigation on canopy temperature and photosynthetic characteristics in winter wheat. J Agric Sci 156(1):13-23. https://doi.org/10.1017/S0021 859617000946

Publisher's Note Springer Nature remains neutral with regard to jurisdictional claims in published maps and institutional affiliations. 